\title{
Market Scenario of Commercially Available Millet Products
}

\author{
Rezwanullah Rafed ${ }^{1}$, Jamuna K.V ${ }^{2}$ \\ ${ }^{1}$ MSc Student, Dept. FSN, UAS, GKVK, Bangalore \\ ${ }^{2}$ Professor. AICRP on FSN, UAS, GKVK, Bangalore
}

\begin{abstract}
Millets are nutritious and serve as food for several million people. Nowadays, different types of millet products are available in Bengaluru city. This study was taken up to assess availability of different processed millet products and their packaging and labelling details. Hundred processed millet products were collected from selected shops namely; organic shops, supermarkets and general stores in Bengaluru city. Collected products were classified based on RTC and RTE. The results showed that Out of hundred products 52 were RTC and 48 were RTE, out of 48 RTE; 10 were from organic and remaining 38 were regular products, whereas in RTC 36 were organic and 16 were regular products. The major millet products available in the market were made of finger millet and foxtail millet. Most of the millet products were available in supermarket compared to organic shops and general stores. Most of RTC millet products were based on flours and RTE were mainly bakery products. Most of the RTC products were packed using polypropylene and silver foil where as maximum RTE products were packed in plastic boxes. Most of millet products in both RTC and RTE had the labeling details according to the FSSAI standard. Most of organic products were compiled by FSSAI standard compared to regular category.
\end{abstract}

Keywords: Millet products, ready - to - cook, ready - to - eat, organic, regular, FSSAI, packaging and labelling

\section{Introduction}

Millets are classified as small-grained cereals that include a large number of different botanical species. Originated by the domestication of wild African grasses in the Nile valley and the Sahel zone, millets were subsequently taken to China and India. These cereals tolerate arid conditions and possess a small, highly nutritious grain that stores well. Millets are used locally, both as a food and as a livestock feed. In all areas where they are cultivated, millets are used in traditional beer brewing. There are also used as a feed for birds [1].

Among rain fed crops, millet as a group figure prominently. India is the largest producer of millets, which are often referred to as coarse cereals. However, realizing the nutrient composition of these grains they are now considered as "nurtricereals". Sorghum (Sorghum bicolor), pearl millet (Pennisetum glaucum) and a group of six small millets together constitute the millets family. The group of small millets is represented by finger millet (Panicum sumatrense), kodo millet (Paspalum scrobiculatum), foxtail millet ( Setaria italic), and proso millet (Panicum miliaceum) little millet(Panicum sumatrens ) and barnyard millet (Echinochloa frumentacea). The mean annual planting area of small millets is around 3.5 million hectors of which finger millet accounts for 50 per cent of the area and $2 / 3^{\text {rd }}$ of the total production [8]. These crops, known by different names in local languages have traditionally been the vital component of dry farming system in India supporting millions of poor and food insecure people. The biggest small millets producing state is Karnataka (56.7\% of total production) followed distantly by Uttarakhand (11.4\%), Tamil Nadu (8.0\%) and Maharashtra (6.5\%). Rest of the states together contribute less than one-fifth of the total production [4].
Food Processing is the conversion of agricultural products to substances which have particular textural, sensory and nutritional properties using a set of methods and techniques called food processes". The demand for convenience products is increasing because of changing life style, socio and economic pattern, increasing number of working women and modified food habits. In recent years there has been increasing recognition for importance of millets and different types of millet processed are available now a day in urban general stores and supermarkets. Exclusive organic shops are also selling processed organic products because people are becoming more and more conscious about their health and prefer to buy healthier processed foods. With this view a study was taken up to assess availability of different processed millet products and their packaging and labelling details.

\section{Literature Survey}

Millet is thought to be one of the first grains cultivated by man. The first recorded reports on the cultivation of millet dates back to about 5,500 BC in China [3]. They are extremely important crops in semi-arid regions where other crops normally do not survive. These millets have been utilized for consumption since pre-historic time for food and animal feed. According to FAO, 2012 report the world total production of millet grains at last count was 762712 metric tons and the top producer was India with an annual production of 334500 tons (43.85\%) [7].

Coarse cereals such as barley, jowar, bajra, ragi, and other small millets are the major components of the traditional Indian food basket for the poor in India. These are grown predominantly in the rain-fed regions of Karnataka, Maharashtra, Tamil Nadu, Madhya Pradesh, Rajasthan, Haryana and Gujarat. Despite a decline in area under cultivation for these crops, production increased due to increase in yield. The decline in the area coverage under 


\section{International Journal of Science and Research (IJSR) \\ ISSN (Online): 2319-7064}

Index Copernicus Value (2015): 78.96 | Impact Factor (2015): 6.391

coarse cereals was from 28.71 million hectares in 2006-07 to 24.15 million hectares in 2014-15. However, the productivity of coarse cereals has increased significantly during this period from $1,182 \mathrm{~kg}$ per hectare to $1,729 \mathrm{~kg}$ per hectare. The increase in productivity was observed in almost all the major coarse cereals producing states resulting in an increase in the total production of coarse cereals from 33.92 million tonnes in 2006-07 to 41.75 million tonnes in 2014$15[5]$.

Singh [9] was conducted in a study that showed, Metalized polyester was found to be the most suitable for the packaging of millet-wheat composite flours as it could be kept up to 55-65 days under accelerated condition without any significant loss of quality $(\mathrm{p} \leq 0.05)$.

\section{Methodology}

Different types of millet products were collected from 3 different shops namely; Organic shops, super markets and general stores. Minimum five to maximum ten shops based on the availability from each category were selected and 100 different products were collected from these shops in and around Bengaluru rural and urban taluk. Samples size was restricted to 100 numbers. Care was taken to collect only fresh samples that are from 0 to $5^{\text {th }}$ day based on the date of manufacture printed on the cover. All the products were divided in to organic and regular products based on the commitment made on the label. These products were further classified in to ready to cook (RTC) and ready to eat (RTE) products for further analysis. Selected samples were studied for packaging materials used. Examination of the labelling was examined as per FSSAI procedures. The results were compared with FSSAI standard labelling rules and procedures of FSSAI, 2012 [2].

\section{Results and Discussion}

Hundred millet products were collected from different categories of shops; namely super markets, general stores and organic shops in Bengaluru city and taluk. The products included ready- to - cook (RTC) and ready - to - eat (RTE) millet products. Among those millet products that were collected from market; 52 products were in the form of ready- to - cook and 48 products were in the form of ready to - eat millet products. Out of 48 RTE 10 were from organic and remaining 38 were regular products, whereas in RTC 36 were organic and 16 were regular products. Statistically there was significant difference at $5 \%$ level (Table 1).

Out of hundred collected millet products in both RTC and RTE, most of them were available in super market compared to local shops and organic shops. Organic products were available in organic shops as well as supermarket. Local shops sold only regular millet products and most of them were RTE products. Statistically there was significant difference at $5 \%$ (Table 2).

Most of the processed millet products were available in the market, were made with finger millet, foxtail millet and mixed millets as compared to other types of millet. Organic RTE products were made by foxtail millet (30\%) when compared to finger millet and mixed millet. Out of 38 regular RTE products 15 were from finger millet, 11 were from foxtail millet and remaining was from other millets (Table 3). Among ready - to - cook millet products (RTC) in both organic and regular, most of them were in the form of flour $(61.11 \%)$ as compared to other types of millet products available in market in the form of RTC. There was no malt product available in organic category but there were infant food and nutria mix which were also malted but named differently (Fig 1).

Most of ready - to - eat millet products were in the form of bakery products. Among bakery products cookies were most abundantly available followed by biscuits and rusk in both organic and regular category. It was surprising to note that ready-to - eat finger millet ambli (type of kanji) was also available in the market under regular category (Fig 2).

Table 1: Classification of commercially available processed millet products

\begin{tabular}{|c|c|c|c|c|c|}
\hline \multirow{2}{*}{ Type of Products } & \multicolumn{2}{|c|}{ Organic } & \multicolumn{2}{|c|}{ Regular } & Total \\
\hline & $\mathrm{N}$ & $\%$ & $\mathrm{~N}$ & $\%$ & $\mathrm{~N}$ \\
\hline Ready - to -cook & 36 & 78.26 & 16 & 29.63 & 52 \\
\hline Ready - to - eat & 10 & 21.74 & 38 & 70.37 & 48 \\
\hline Total & 46 & 100 & 54 & 100 & 100 \\
\hline$x^{2}$ & \multicolumn{5}{|c|}{2.00} \\
\hline
\end{tabular}

*Significant at $5 \%$ level

Table 2: Millet products available in different types of shops

\begin{tabular}{|c|c|c|c|c|c|}
\hline \multirow{2}{*}{ Types of shop } & \multicolumn{2}{|c|}{ Ready - to - cook } & \multicolumn{2}{c|}{ Ready - to - eat } & Total \\
\cline { 2 - 5 } & Organic & Regular & Organic & Regular & \\
\hline Super markets & 14 & 11 & 2 & 22 & 49 \\
\hline Local shops & 7 & 5 & - & 16 & 28 \\
\hline Organic shops & 15 & - & 8 & - & 23 \\
\hline Total & 36 & 16 & 10 & 38 & 100 \\
\hline $\boldsymbol{x}^{2}$ & \multicolumn{2}{|c|}{$\mathbf{6 . 0 0}^{2}$} & \multicolumn{6}{|c|}{$\mathbf{6 . 0 0}^{*}$} & \\
\hline
\end{tabular}

*Significant at $5 \%$ level

Table 3: Types of millet products available in the market from different millets

\begin{tabular}{|c|c|c|c|c|c|c|c|c|}
\hline & \multicolumn{3}{|c|}{ Organic } & \multicolumn{4}{c|}{ Regular } \\
\cline { 2 - 10 } Type of millet & $\begin{array}{c}\text { RTE* }^{*} \\
\text { (Total 10 } \\
\text { No) }\end{array}$ & $\begin{array}{c}\text { RTC* } \\
\text { (Total 36 } \\
\text { No) }\end{array}$ & \multicolumn{2}{c|}{$\begin{array}{c}\text { RTE } \\
\text { (Total 38 No) }\end{array}$} & \multicolumn{2}{c|}{$\begin{array}{c}\text { RTC } \\
\text { (Total 16 } \\
\text { No) }\end{array}$} \\
\cline { 2 - 10 } & No & $\%$ & No & $\%$ & No & $\%$ & No & $\%$ \\
\hline Finger Millet & 2 & 20 & 8 & 22.22 & 15 & 39.47 & 11 & 68.75 \\
\hline Kodo Millet & 1 & 10 & - & - & 3 & 7.89 & - & - \\
\hline Foxtail Millet & 3 & 30 & 4 & 11.11 & 11 & 28.94 & 1 & 6.25 \\
\hline Barnyard Millet & - & - & 2 & 5.55 & - & - & - & - \\
\hline Proso Millet & - & - & 3 & 8.33 & 2 & 5.26 & - & - \\
\hline Little Millet & - & - & 8 & 22.22 & 2 & 5.26 & - & - \\
\hline Pearl Millet & 2 & 20 & - & - & 3 & 7.89 & - & - \\
\hline Mixed millet & 2 & 20 & 11 & 30.55 & 2 & 5.26 & 4 & 25 \\
\hline
\end{tabular}

*RTE $=$ Ready - to - eat, $\mathrm{RTC}=$ Ready - to - cook

Details of labeling on the packaging material of millet products were studied and compared with FSSAI standard for packaging (2012). Most of the RTC products were packed using polypropylene and silver foil where as maximum RTE products were packed in plastic boxes. However, there was significant difference found between packaging materials of millet products at $5 \%$ level (Table 6).

\section{Volume 6 Issue 7, July 2017 www.ijsr.net}




\section{International Journal of Science and Research (IJSR) \\ ISSN (Online): 2319-7064 \\ Index Copernicus Value (2015): 78.96 | Impact Factor (2015): 6.391}

The labeling details showed that, products in both RTC and RTE had the label according to the FSSAI standard, except in few products collected from regular shops which did not comply by FSSAI mandatory regulations. However all organic millet products in both RTC and TRE had the mandatory information (Table 9 and 10).According to FSSAI standard, if the logo square is less than $100 \mathrm{~cm}$; the logo size should be less than $3 \mathrm{~mm}$, interestingly logo size of all collected millet products was $3 \mathrm{~mm}$ in less than $100 \mathrm{~cm}$ logo square.

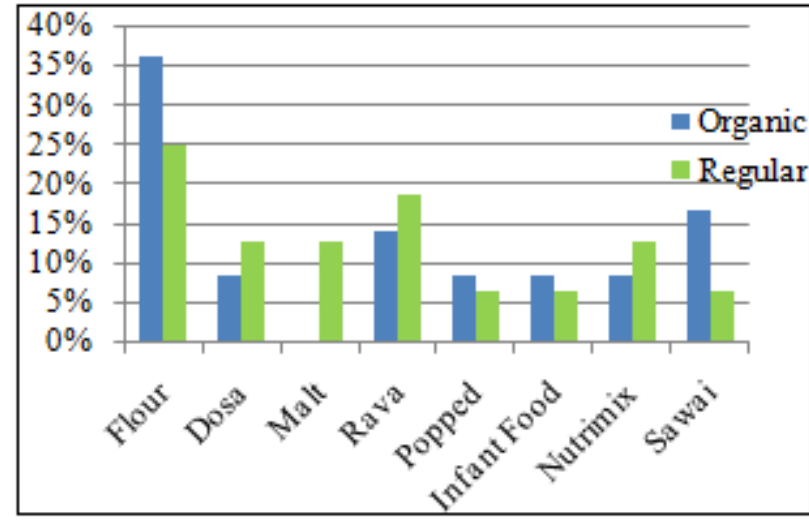

Figure 1: Types of processed ready - to - cook millet products available in market

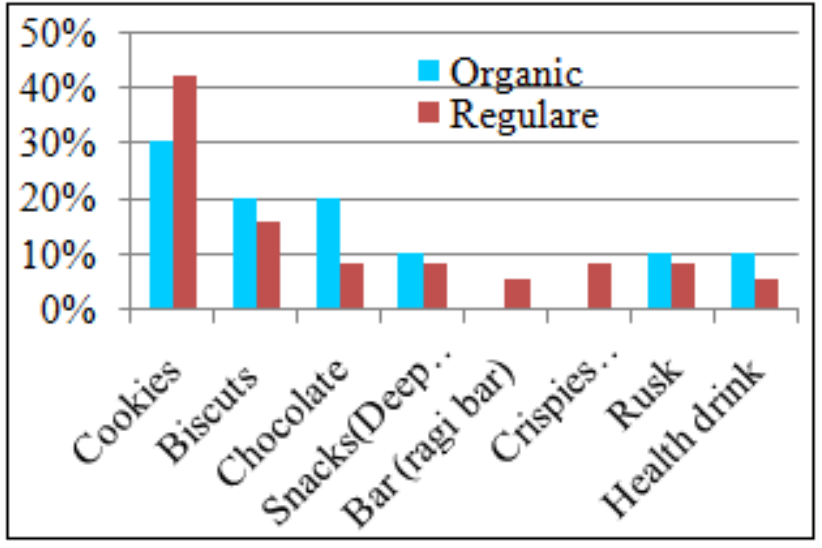

Figure 2: Types of processed ready - to - eat millet products available in market

Table 6: Types of packaging materials used for millet products

\begin{tabular}{|c|c|c|}
\hline Packaging Materials & Ready - to - cook & Ready - to - eat \\
\hline Poly propylene & 15 & 14 \\
\hline Paper carton & 13 & 3 \\
\hline Silver foils & 18 & 3 \\
\hline Laminated metalined films & 6 & 10 \\
\hline Hard plastic boxes & 0 & 18 \\
\hline Mean \pm SD & $10.4 \pm 6.53$ & $9.6 \pm 5.95$ \\
\hline$x^{2}$ & \multicolumn{2}{|c|}{$15.00^{*}$} \\
\hline
\end{tabular}

$*$ Significant at $5 \%$ level

Table 9: Details of labelling on the packaging material of RTC millet products (according to FSSAI)

\begin{tabular}{|c|c|c|c|c|c|c|c|c|c|c|c|c|c|c|}
\hline \multirow[t]{2}{*}{ Types of Product } & \multirow[t]{2}{*}{$\begin{array}{c}\text { No of } \\
\text { Product } \\
(48 \mathrm{No})\end{array}$} & \multirow[t]{2}{*}{$\begin{array}{l}\text { FSSAI } \\
\text { Certifi- } \\
\text { Cation }\end{array}$} & \multirow[t]{2}{*}{$\begin{array}{c}\text { Products } \\
\text { Details }\end{array}$} & \multirow[t]{2}{*}{$\begin{array}{c}\text { Food } \\
\text { Additive }\end{array}$} & \multirow[t]{2}{*}{$\begin{array}{l}\text { Nutrition } \\
\text { labeling }\end{array}$} & \multirow[t]{2}{*}{$\begin{array}{c}\text { Net. } \\
\text { Wt }\end{array}$} & \multirow[t]{2}{*}{$\begin{array}{c}\text { Lot/Code/ } \\
\text { Batch }\end{array}$} & \multirow[t]{2}{*}{$\begin{array}{c}\text { Name/ } \\
\text { Address }\end{array}$} & \multirow[t]{2}{*}{ Price } & \multicolumn{3}{|c|}{ *Marketing Date } & \multicolumn{2}{|c|}{\begin{tabular}{|c|} 
Veg/Nonvege \\
Declaration with \\
Symbol \\
\end{tabular}} \\
\hline & & & & & & & & & & B.B.D & P.D & E.D & Veg & Non \\
\hline Flour & $17(\mathrm{No})$ & & & & & & & & & & & & & \\
\hline Organic & 13 & 13 & 13 & 13 & 13 & 13 & 13 & 13 & 13 & 13 & 13 & 13 & 13 & - \\
\hline Regular & 4 & - & 4 & 4 & - & 4 & - & 3 & 4 & - & 17 & - & 4 & - \\
\hline Dosamix & $5(\mathrm{No})$ & & & & & & & & & & & & & \\
\hline Organic & 3 & 3 & 3 & 3 & 3 & 3 & 3 & 3 & 3 & 3 & 3 & 3 & 3 & - \\
\hline Regular & 2 & - & 2 & 2 & - & - & - & 2 & 2 & - & 2 & - & 2 & - \\
\hline Malt (ragi malt) & $2(\mathrm{No})$ & & & & & & & & & & & & & \\
\hline Organic & - & - & - & - & - & - & - & - & - & - & - & - & - & - \\
\hline Regular & 2 & - & 2 & 2 & - & 1 & - & 2 & 2 & - & 2 & - & 2 & - \\
\hline Rava & $8(\mathrm{No})$ & & & & & & & & & & & & & \\
\hline Organic & 5 & 5 & 5 & 5 & 5 & 5 & 5 & 5 & 5 & 5 & 5 & 5 & 5 & - \\
\hline Regular & 3 & - & 3 & 2 & - & 2 & - & 2 & 3 & - & 3 & - & 3 & - \\
\hline Popped mix & $4(\mathrm{No})$ & & & & & & & & & & & & & \\
\hline Organic & 3 & 3 & 3 & 3 & 3 & 3 & 3 & 3 & 3 & 3 & 3 & 3 & 3 & - \\
\hline Regular & 1 & - & 1 & - & - & 1 & - & 1 & 1 & - & 1 & - & 1 & - \\
\hline Infant Food & $4(\mathrm{No})$ & & & & & & & & & & & & & \\
\hline Organic & 3 & 3 & 3 & 3 & 3 & 3 & 3 & 3 & 3 & 3 & 3 & 3 & 3 & - \\
\hline Regular & 1 & - & 1 & 1 & - & 1 & - & - & 3 & - & 1 & - & 3 & - \\
\hline Nutrimix & $5(\mathrm{No})$ & & & & & & & & & & & & & \\
\hline Organic & 3 & 3 & 3 & 3 & 3 & 3 & 3 & 3 & 3 & 3 & 3 & 3 & 3 & - \\
\hline Regular & 2 & - & 2 & 2 & - & - & - & 2 & 2 & - & 2 & - & 2 & - \\
\hline Sawai & $7(\mathrm{No})$ & & & & & & & & & & & & & \\
\hline Organic & 6 & 6 & 6 & 6 & 6 & 6 & 6 & 6 & 6 & 6 & 6 & 6 & 6 & - \\
\hline Regular & 1 & - & 1 & 1 & - & 1 & - & 1 & 1 & - & 1 & 1 & 1 & - \\
\hline
\end{tabular}

*B.B.D= Best Before Date, P.D= Packaging Date, E.D =Expire Date 


\section{International Journal of Science and Research (IJSR) \\ ISSN (Online): 2319-7064}

Index Copernicus Value (2015): 78.96 | Impact Factor (2015): 6.391

Table 10: Details of labelling on the packaging material of RTE millet products (According to FSSAI)

\begin{tabular}{|c|c|c|c|c|c|c|c|c|c|c|c|c|c|c|}
\hline \multirow[t]{2}{*}{ Types of Product } & \multirow[t]{2}{*}{$\begin{array}{l}\text { No of } \\
\text { Product } \\
(48 \mathrm{No})\end{array}$} & \multirow[t]{2}{*}{$\begin{array}{l}\text { FSSAI } \\
\text { Certifi- } \\
\text { Cation }\end{array}$} & \multirow[t]{2}{*}{\begin{tabular}{|c} 
Products \\
Details
\end{tabular}} & \multirow[t]{2}{*}{$\begin{array}{c}\text { Food } \\
\text { Additive }\end{array}$} & \multirow[t]{2}{*}{$\begin{array}{c}\text { Nutrition } \\
\text { labeling }\end{array}$} & \multirow[t]{2}{*}{$\begin{array}{l}\text { Net. } \\
\text { Wt }\end{array}$} & \multirow[t]{2}{*}{\begin{tabular}{|c|} 
Lot/ \\
Code/ \\
Batch
\end{tabular}} & \multirow[t]{2}{*}{$\begin{array}{c}\text { Name/ } \\
\text { Address }\end{array}$} & \multirow[t]{2}{*}{ Price } & \multicolumn{3}{|c|}{ *Marketing Date } & \multicolumn{2}{|c|}{$\begin{array}{c}\text { Veg/Nonvege } \\
\text { Declaration with } \\
\text { Symbol }\end{array}$} \\
\hline & & & & & & & & & & B.B.D & P.D & E.D & Veg & Non \\
\hline Cookies & $21(\mathrm{No})$ & & & & & & & & & & & & & \\
\hline Organic & 4 & 4 & 4 & 4 & 4 & 4 & 4 & 4 & 4 & 4 & 4 & 4 & 4 & - \\
\hline Regular & 17 & 15 & 17 & 17 & 15 & 15 & 15 & 17 & 17 & 15 & 17 & 17 & 17 & - \\
\hline Biscuits & $8(\mathrm{No})$ & & & & & & & & & & & & & \\
\hline Organic & 2 & 2 & 2 & 2 & 2 & 2 & 2 & 2 & 2 & 2 & 2 & 2 & 2 & - \\
\hline Regular & 6 & 2 & 6 & 5 & 2 & 6 & 2 & 6 & 6 & 2 & 6 & 4 & 6 & - \\
\hline Chocolate & $5(\mathrm{No})$ & & & & & & & & & & & & & \\
\hline Organic & 2 & 2 & 2 & 2 & 2 & 2 & 2 & 2 & 2 & 2 & 2 & 2 & 2 & - \\
\hline Regular & 3 & - & 3 & 2 & - & 1 & - & 3 & 3 & - & 3 & 1 & 3 & - \\
\hline Snacks (Deep fried) & $4(\mathrm{No})$ & & & & & & & & & & & & & \\
\hline Organic & 1 & 1 & 1 & 1 & 1 & 1 & 1 & 1 & 1 & 1 & 1 & 1 & 1 & - \\
\hline Regular & 3 & 1 & 3 & 2 & 1 & 2 & - & 2 & 2 & 2 & 3 & 2 & 3 & - \\
\hline $\begin{array}{c}\text { Bar (Finger millet } \\
\text { bar) }\end{array}$ & $2(\mathrm{No})$ & & & & & & & & & & & & & \\
\hline Organic & - & - & - & - & - & - & - & - & - & - & - & - & - & - \\
\hline Regular & 2 & - & 2 & - & - & 2 & - & 2 & 2 & - & 2 & - & 2 & - \\
\hline Crispy (Extruded) & $3(\mathrm{No})$ & & & & & & & & & & & & & \\
\hline Organic & - & - & - & - & - & - & - & - & - & - & - & - & - & - \\
\hline Regular & 3 & - & 3 & 1 & - & 1 & - & 3 & 3 & - & 3 & 1 & 3 & - \\
\hline Rusk & $4(\mathrm{No})$ & & & & & & & & & & & & & \\
\hline Organic & 1 & 1 & 1 & 1 & 1 & 1 & 1 & 1 & 1 & 1 & 1 & 1 & 1 & - \\
\hline Regular & 3 & 2 & 3 & 2 & 2 & 2 & 2 & 3 & 3 & 2 & 3 & 2 & 3 & - \\
\hline Finger millet Ambli & $1(\mathrm{No})$ & & & & & & & & & & & & & \\
\hline Organic & - & - & - & - & - & - & - & - & - & - & - & - & - & - \\
\hline Regular & 1 & - & 1 & 1 & - & 1 & - & 1 & 1 & - & 1 & 1 & 1 & - \\
\hline
\end{tabular}

*B.B.D= Best Before Date, P.D= Packaging Date, E.D =Expire Date

\section{Conclusion}

Different types of millet products were collected from Bengaluru city to study the quality status of the products. About hundred millet products were collected from different sources such as super market, general stores and organic shops; and studied the details. Most of the millet products were available in the super markets, were complied with FSSAI standard, so it is better to prefer supermarket products compared to general stores or local shops. Training is required towards for small entrepreneurs regarding getting the licence from FSSAI and also regarding proper processing and ensuring proper packaging of the processed products.

\section{References}

[1] FAO, 1995, Sorghum and millets in human nutrition. FAO food and nutrition series, 27: 8-11.

[2] FOOD SAFETY AND STANDARD AUTHORITY OF INDIA., 2012, Manual of methods of analysis of foods, cereals and cereal products.MHSW, GOI, New Delhi.pp. $12-23$

[3] FULLER QDORIAN., LING QIN., EMMA HARVEY., 2007,A Critical assessment of early agriculture in East Asia, with emphasis on lower yangzte rice Domestication. Pradghara. Journal of the Uttar Pradesh State Archaeology Department-Farmers in Global Perspective. Seminar of Uttar Pradesh State Department of Archaeology, Luck now, India, 18-20 January 2006, pp. 11- 12.

[4] HARIPRASANNA K., 2016, Small Millets in IndiaCurrent scenario and way forward, Indian institute of Millets Research., pp. 11.
[5] INDIAN AGRICULTURE 2015-16., 2016, Agricultural Production and Programmes. GOI, Ministry of Agriculture \& Farmers Welfare, Department of Agriculture, Cooperation \& Farmers Welfare Directorate of Economics and Statistics New Delhi, pp.143 - 172.

[6] MOLNÁR., 2009, Food Quality and Standards - Vol. II Food Quality Indices., (CEncyclopedia of Life Support Systems (EOLSS).

[7] SALEH, S.M., AHMED QING ZHANG., JING CHEN., AND QUN SHEN., 2013, Millet grains: nutritional quality, processing, and potential health benefits. Comprehensive review in food science and food safety., 12: $281-295$.

[8] SEETHARAM, A., 2001, Annual report 2000-01. All India co-ordinated small millet improvement project, Bangalore, pp. 1- 28.

[9] SINGH KP, MISHRA HN AND SAHA S., 2012, Changes during accelerated storage in millet-wheat composite flours for bread. Food BioprocessTechnol J., 5(5): 2003 2011

\section{Author Profile}

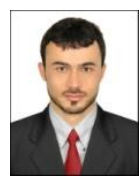

Rezwanullah Rafed, MSc Student of Food Science and Nutrition, University of Agricultural Science, GKVK, Bengaluru.

Dr. Jamuna, Professor of Food Science and Nutrition, All India Coordinated Research Project, University of Agricultural Science, GKVK, Bengaluru. 